\title{
Perhitungan Kehilangan Pratekan Total dengan Memakai Teori Kemungkinan
}

\author{
M. Sigit Darmawan \\ Dosen Jurusan Diploma Teknik Sipil, FTSP - ITS \\ Email: msdarmawan@ce.its.ac.id
}

\begin{abstract}
ABSTRAK
Salah satu tahapan perhitungan yang penting untuk perhitungan konstruksi beton pratekan adalah perhitungan besarnya kehilangan pratekan (loss of prestress). Pada umumnya perhitungan kehilangan pratekan dilakukan dengan memakai anggapan bahwa semua variabel yang berpengaruh bersifat deterministik. Anggapan ini menjadi kurang tepat bila dikaitkan dengan sifat-sifat beton dan baja pratekan yang mempunyai tingkat variabilitas yang tertentu. Pada studi ini akan disajikan perhitungan kehilangan pratekan akibat susut dan rangkak pada beton serta relaksasi pada baja, dengan memperhitungkan variabilitas sifat-sifat beton dan baja pratekan. Variabitas beton dan baja pratekan akan diperhitungkan dalam perhitungan dengan memakai analisis teori kemungkinan (probability analysis). Mengingat sangat terbatasnya data parameter statistik beton dan baja pratekan untuk kondisi Indonesia, maka parameter statistik yang diperlukan untuk perhitungan kehilangan pratekan akan diambil dari berbagai penelitian sebelumnya yang pada umumnya dilakukan di luar Indonesia. Hasil studi menunjukkan bahwa memasukkan variabilitas sifat-sifat beton dan baja pratekan mempunyai efek yang cukup besar terhadap besarnya kehilangan pratekan. Kehilangan pratekan akibat susut dan rangkak beton serta relaksasi baja dan kombinasi dari ketiga faktor tersebut mempunyai mempunyai rata-rata sebesar $3.86 \%, 10.05 \%, 4.31 \%$ dan $18.22 \%$, dengan koefisien penyebaran sebesar $57 \%$, 35\%, $18 \%$ dan $25 \%$.

Kata Kunci: Kehilangan Pratekan Total, Susut, Rangkak, Relaksasi, Probability Analysis
\end{abstract}

\section{PENDAHULUAN}

Perhitungan kehilangan pratekan total (loss of prestress) merupakan salah satu tahapan yang penting dalam pehitungan konstruksi beton pratekan. Besarnya kehilangan pratekan menentukan seberapa besar gaya yang diperlukan untuk pemberian pratekanan agar struktur beton pratekan mampu memikul beban-beban yang direncanakan secara efektif. Meskipun kesalahan dalam perhitungan kehilangan pratekan, tidak mempunyai dampak yang berarti terhadap kekuatan maksimum penampang beton pratekan, kesalahan dalam perkiraan kehilangan pratekan mempunyai efek yang besar terhadap tingkat pelayanan (serviceability) dari struktur beton pratekan. Masalah yang mungkin timbul akibat kurang tepatnya perkiraan kehilangan pratekan adalah terjadinya lendutan yang berlebihan dan atau retak yang berlebihan.
Pada umumnya perhitungan kehilangan pratekan dilakukan dengan anggapan semua parameter beton dan baja pratekan bersifat deterministik (dapat ditentukan dengan pasti). Tentu saja anggapan ini kurang tepat bila dikaitkan dengan sifat-sifat material beton yang pada umumnya mempunyai tingkat variabilitas yang cukup besar. Seperti halnya beton, material baja pratekan juga mempunyai variabilitas tertentu, meskipun tidak sebesar material beton.

Pada studi ini akan dilakukan perhitungan kehilangan pratekan akibat susut dan rangkak pada beton serta relaksasi pada baja pratekan dengan memasukkan variabitas sifat-sifat beton dan baja. Variabilitas sifat-sifat beton dan baja akan diperhitungkan dengan memakai analisis teori kemungkinan (probability analysis). 


\section{TINJ AUAN PUSTAKA}

Perhitungan kehilangan pratekan lazimnya dilakukan dengan mengacu kepada perumusan empiris yang diberikan oleh peraturan beton (code). Salah satu code yang memberikan perumusan yang cukup jelas tentang cara-cara perhitungan kehilangan pratekan akibat susut dan rangkak pada beton adalah AS 3600 . Sebaliknya untuk ACI 318 tidak memberikan perumusan tertentu untuk memperhitungkan kehilangan pratekan akibat kedua faktor tersebut.

Seperti diketahui susut dan rangkak adalah deformasi beton yang tergantung waktu dan meningkat dengan bertambahnya waktu. Selain itu besarnya rangkak juga dipengaruhi besarnya tegangan yang bekerja. Ada beberapa model yang dapat digunakan untuk memprediksi kedua fenomena tersebut, mulai perumusan sederhana seperti yang diberikan dalam peraturan beton (code), sampai dengan perumusan yang cukup komplex seperti diusulkan oleh Bazant dan Baweja (1995).

Beberapa peneliti, antara lain Gilbert (1988), Koutsoukis (1996), Khor (1999) telah melakukan studi perbandingan berbagai model untuk perhitungan susut dan rangkak pada beton, termasuk perumusan yang diberikan oleh peraturan beton seperti AS 3600, ACI 209, CEB-FIP. Namun demikian hasil studi perbandingan tersebut, belum dapat menyimpulkan apakah model tertentu memprediksi lebih baik dibandingkan dengan model yang lain. Hasil studi perbandingan tersebut juga menunjukkan ada perbedaan yang cukup besar antara model yang satu dengan yang lainnya serta kurang berhasil dalam memprediksi data tes yang tersedia (Gilbert,1988). Hasil studi juga menghasilkan kesimpulan bahwa perumusan AS 3600 memberikan nilai yang merupakan rata-rata dari model yang lainnya. Berdasarkan hasil studi tersebut, maka pada penelitian ini akan dipakai AS 3600 untuk menentukan besarnya susut dan rangkak pada beton.

\section{PERUMUSAN CREEP DAN SUSUT BETON 3.1. Susut Beton}

Regangan akibat susut pada beton pada umur $t$ (hari) dapat ditentukan dengan perumusan sebagai berikut (AS 3600, 2002):

$\varepsilon_{\mathrm{cs}}(\mathrm{t})=\mathrm{k}_{1} \varepsilon_{\mathrm{cs.}}$

dimana $\varepsilon_{\text {cs.b }}$ adalah regangan susut dasar rencana (basic design shrinkage strain) dan $\mathrm{k}_{1}$ adalah factor modifikasi untuk memasukkan pengaruh:(i)umur beton; (ii)tipe lingkungan; dan (iii) ukuran dan bentuk penampang. Bila tidak ada data dari hasil tes untuk menentukan $\varepsilon_{\text {cs.b }}$, AS 3600 menyarankan untuk memakai nilai sebesar $700 \times 10^{-6}$. Namun demikian perlu dicatat bahwa nilai sebenarnya $\varepsilon_{\text {cs.b }}$ bervariasi antara $500 \times 10^{-6} \mathrm{~s} / \mathrm{d} 1000 \times 10^{-6}$. Sedangkan nilai $k_{1}$ ditentukan sesuai perumusan Gilbert (1990) sebagai berikut

$\mathrm{k}_{1}=\frac{\mathrm{k}_{4} \mathrm{k}_{5}\left(\mathrm{t}-\mathrm{t}_{\mathrm{c}}\right)^{0.7}}{\left(\mathrm{t}-\mathrm{t}_{\mathrm{c}}\right)^{0.7}+\mathrm{k}_{6}}$

dimana

$\mathrm{k}_{4}=0.62+1.5 \mathrm{e}^{-.005 \mathrm{t}_{\mathrm{h}}}$

$\mathrm{k}_{5}=\frac{4.0-0.04 \times \mathrm{h}}{3}$

$\mathrm{k}_{6}=\frac{\mathrm{t}_{\mathrm{h}}}{7}$

dan $t_{c}$ waktu (dalam hari) ketika curing dihentikan. Pada persamaan diatas $\mathrm{h}$ adalah rata-rata kelembaban tahunan (\%), and th adalah tebal teoritis penampang $(\mathrm{mm})$ yang didefinisikan sebagai

$$
\mathrm{t}_{\mathrm{h}}=\frac{2 \mathrm{~A}_{\mathrm{g}}}{\mathrm{u}_{\mathrm{e}}}
$$

dengan Ag adalah luas penampang total dan Ue adalah keliling penampang yang berhubungan langsung dengan udara.

\subsection{Rangkak Beton}

Regangan akibat rangkak pada beton pada umur $t$ (hari) dapat dihitung dengan perumusan sebagai berikut (AS 3600,2002 ): 
$\varepsilon_{c c}(t)=\phi_{c c}(t) \frac{f_{c}}{E_{c}(28)}$

dimana

$\phi_{\mathrm{cc}}(\mathrm{t})=\mathrm{k}_{2} \mathrm{k}_{3} \phi_{c c . b}$

dimana $f_{c}$ adalah tegangan pada beton, $\mathrm{E}_{c}$ (28) adalah modulus elastis beton pada umur 28 hari, $\phi_{\text {cc.b }}$ adalah factor rangkak dasar (basic creep factor), yang tergantung pada kuat tekan beton (lihat Tabel 1). Perlu dicatat bahwa nilai $\phi_{\text {cc.b }}$ dapat bervariasi sampai dengan $\pm 30 \%$.

Tabel 1: Faktor Rangkak Dasar $\phi_{\text {cc.b }}$.

\begin{tabular}{cccccc}
\hline $\begin{array}{c}\mathrm{f}_{\mathrm{c}} \mathrm{c} \\
(\mathrm{MPa})\end{array}$ & 20 & 25 & 32 & 40 & 50 \\
\hline$\phi_{\text {cc.b }}$ & 5.2 & 4.2 & 3.4 & 2.5 & 2.0 \\
\hline
\end{tabular}

Adapun $\mathrm{k}_{2}$ adalah factor modifikasi seperti halnya faktor $k_{1}$ pada perhitungan susut and $\mathrm{k}_{3}$ faktor untuk memperhitungkan umur beton pada saat gaya pratekan dikerjakan (lihat Gambar 1).

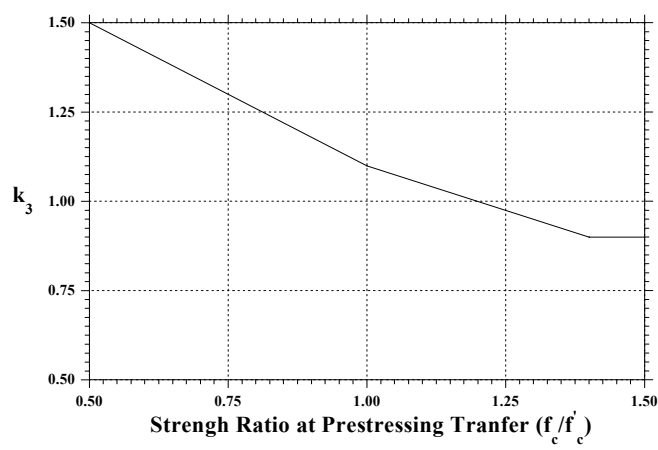

Gambar 1: Koefisien Rangkak k3.

Adapun nilai $k_{2}$ ditentukan dengan memakai perumusan $\mathrm{k}_{2}=\frac{\mathrm{k}_{7} \mathrm{k}_{8}\left(\mathrm{t}-\mathrm{t}_{\mathrm{a}}\right)^{0.7}}{\left(\mathrm{t}-\mathrm{t}_{\mathrm{a}}\right)^{0.7}+\mathrm{k}_{9}}$

dimana

$$
\begin{aligned}
& \mathrm{k}_{7}=0.76+0.9 \mathrm{e}^{-.008 \mathrm{t}_{\mathrm{h}}} \\
& \mathrm{k}_{8}=1.37-0.011 \times \mathrm{h} \\
& \mathrm{k}_{9}=0.15 \mathrm{t}_{\mathrm{h}} \ldots \ldots \ldots \ldots \ldots
\end{aligned}
$$

dan $t_{a}$ umur (hari) pada saat beban dikerjakan.

\subsection{Relaksasi Baja Pratekan}

Tegangan pada baja pratekan akan berkurang dengan waktu bila baja ditahan dalam kondisi regangan yang tetap. Kejadian ini disebut relaksasi, yang serupa dengan rangkak pada beton. Beberapa faktor yang mempengaruhi besarnya relaksasi antara lain, temperatur, tegangan awal baja dan tipe baja pratekan. Besarnya kehilangan pratekan setelah waktu t (hari) dapat diperkirakan dengan formula sebagai berikut (AS 3600, 2002):

$$
\mathrm{R}_{\mathrm{p}}(\mathrm{t})=\mathrm{k}_{10} \mathrm{k}_{11} \mathrm{k}_{12} \mathrm{k}_{13} \mathrm{R}_{\mathrm{b}}
$$

dimana $k_{10}, k_{11}$ and $k_{12}$ adalah faktor modifikasi untuk memperhitungkan lama pemberian pratekanan, temperatur dan besarnya tegangan awal. $\mathrm{R}_{\mathrm{b}}$ adalah faktor relaksasi dasar, yang tergantung pada tipe baja. Besarnya Rb bervariasi antara $1 \mathrm{~s} / \mathrm{d} 2 \%$ untuk baja dengan relaksasi rendah (low relaxation prestressing steel). Adapun nilai $\mathrm{k}_{10}$ and $\mathrm{k}_{11}$ dapat ditentukan dengan perumusan sebagai berikut:

$\mathrm{k}_{10}=\log \left[5.4\left(\mathrm{t}-\mathrm{t}_{\mathrm{p}}\right)^{1 / 6}\right]$

$\mathrm{k}_{11}=\frac{\mathrm{t}_{\mathrm{e}}}{20} \geq 1.0$

dimana $t_{p}$ adalah waktu ketika baja pratekan ditarik (hari) dan te adalah temperatur rata-rata tahunan $\left({ }^{\circ} \mathrm{C}\right)$. Nilai dari 
$\mathbf{k}_{12}$ tergantung pada proporsi tegangan terhadap tegangan maksimum baja dan dapat ditentukan nilainya berdasarkan Gambar 2.

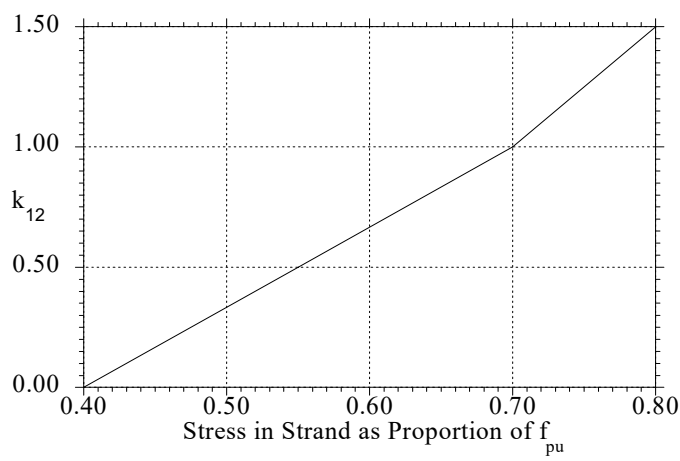

Gambar 2: Koefisien Relaksasi k12

Faktor $\mathrm{k}_{13}$ dipakai untuk memperhitungkan pengaruh susut dan rangkak pada beton terhadap besarnya kehilangan pratekan akibat relaksasi baja dan ditentukan besarnya sebagai

$\mathrm{k}_{13}=\left[1-\frac{\text { kehilangan }(\text { susut }+ \text { rangkak })}{\mathrm{f}_{\mathrm{si}}}\right]$.

dimana $f_{s i}$ adalah tegangan awal pada baja pratekan

\subsection{Parameter Statistik Yang Dipakai}

Mengingat tidak terdokumentasinya data penelitian tentang susut dan rangkak pada beton di Indonesia, maka parameter statistik yang akan dipakai untuk perhitungan kehilangan pratekan dengan memakai analisa teori kemungkinan adalah memakai parameter statistik yang berasal dari penelitian di luar Indonesia (lihat Tabel 2).

Tabel 2: Parameter Statistik Yang Dipakai

\begin{tabular}{|c|c|c|c|c|}
\hline Parameter & Rata-rata & cov & Distribusi & Referensi \\
\hline $\begin{array}{c}\varepsilon_{\text {cs.b }} \\
\text { (regangan susut dasar rencana) }\end{array}$ & $750 \times 10^{-6}$ & $144 \times \times 10^{-6}$ & $\begin{array}{c}\text { Uniform } \\
(500-1000) \times 10^{-6}\end{array}$ & AS 3600 \\
\hline $\begin{array}{c}\phi_{\text {cc.b }} \\
\text { (faktor rangkak dasar) }\end{array}$ & 2.5 & 0.43 & $\begin{array}{l}\text { Uniform } \\
(3.25-1.75)\end{array}$ & AS 3600 \\
\hline $\begin{array}{c}\mathrm{Rb}_{\mathrm{b}}(\%) \\
\text { (faktor relaksasi dasar) }\end{array}$ & 1.5 & 0.29 & $\begin{array}{l}\text { Uniform } \\
(1-2)\end{array}$ & AS 3600 \\
\hline $\begin{array}{c}f_{c}^{\prime}(\mathrm{MPa}) \\
\text { (kuat tekan beton) }\end{array}$ & $\mathrm{F}^{\prime}{ }_{\mathrm{c}}+7.5$ & $\mathrm{~s}^{\mathrm{b}}=6$ & Lognormal & Attard and Stewart (1998) \\
\hline $\begin{array}{c}\mathrm{E}_{\mathrm{c}}(\mathrm{t})(\mathrm{MPa}) \\
\text { (modulus elastis beton) }\end{array}$ & $4600 \sqrt{f_{c}^{\prime}(t)}$ & - & - & Mirza et al. (1979) \\
\hline $\operatorname{ME}^{\mathrm{c}}\left(\mathrm{E}_{c}(\mathrm{t})\right)$ & 1.0 & 0.12 & Normal & - \\
\hline $\begin{array}{c}E_{p}(M P a) \\
\text { (modulus elastis baja) }\end{array}$ & 195000 & 0.02 & Normal & Mirza et al. (1980) \\
\hline $\begin{array}{c}\mathrm{f}_{\mathrm{pu}}(\mathrm{MPa}) \\
\text { (tegangan max baja) }\end{array}$ & $1.04 f_{p k}$ & 0.025 & Normal & Mirza et al. (1980b) \\
\hline $\begin{array}{l}\mathrm{H}(\mathrm{mm}) \\
\text { (Tinggi balok) }\end{array}$ & $\mathrm{H}_{\mathrm{nom}}+0.8$ & $s=3.6$ & Normal & Mirza and McGregor (1979b) \\
\hline $\begin{array}{c}\text { B (mm) } \\
\text { (lebar balok) }\end{array}$ & $B_{n o m}+2.5$ & $S=3.7$ & Normal & Mirza and McGregor (1979b) \\
\hline ME(Susut) & 1.0 & 0.34 & Normal & Bazant and Baweja (1995) \\
\hline ME(Rangkak) & 1.0 & 0.23 & Normal & Bazant and Baweja (1995) \\
\hline $\begin{array}{c}\mathrm{RH}(\%) \\
\text { (kelembaban relatif) }\end{array}$ & 80 & 0.1 & Normal & Stewart (1996) \\
\hline $\begin{array}{c}\mathrm{te}_{\mathrm{e}}\left({ }^{\circ} \mathrm{C}\right) \\
\text { (temperatur rata-rata tahunan) }\end{array}$ & 27.5 & 0.1 & Normal & - \\
\hline
\end{tabular}

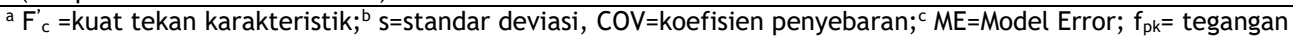
maksimum baja karakteristik 
Analisa teori kemungkinan dilakukan dengan melakukan simulasi Monte Carlo. Simulasi Monte Carlo dilakukan dengan memasukkan sebuah nilai dari setiap variabel yang terlibat kedalam perumusan kehilangan pratekan dengan secara acak (random) sesuai dengan tipe distribusinya. Langkah ini dilakukan berulangkali untuk mendapatkan nilai kehilangan pratekan yang dapat diterima secara statistik, misalnya dengan melakukan 1000000 simulasi. Dengan tersedianya perangkat keras komputer yang relatif cepat, simulasi sebanyak ini telah dapat dilakukan dalam waktu yang relatif singkat.

\section{APLIKASI PERHITUNGAN}

Sebagai contoh perhitungan, maka dilakukan perhitungan kehilangan pratekan untuk balok pratekan dengan dimensi seperti Gambar 3.

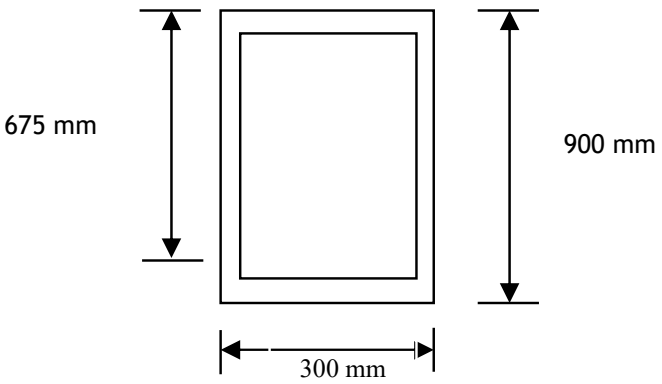

Gambar 3: Balok 300 mm x 900 mm.

Sedangkan data disain yang dipakai adalah sebagai berikut:

$f^{\prime}{ }_{c}$ (kuat tekan $)=40 \mathrm{MPa}$

Aps (luas penampang baja) $=3643 \mathrm{~mm}^{2}$

$f^{\prime}{ }^{\prime}$ (kuat tekan saat transfer) $=30 \mathrm{MPa}$

$E_{p}$ (modulus elastis baja) $=195000 \mathrm{MPa}$

$\mathrm{f}_{\mathrm{si}}$ (tegangan awal baja pratekan) $=1100 \mathrm{MPa}$

\section{HASIL YANG DIPEROLEH}

Selanjutnya dilakukan perhitungan besarnya kehilangan pratekan akibat susut dan rangkak pada beton serta relaksasi pada baja setelah umur 30 tahun, dimana pada umumnya pada umur ini nilai kehilangan pratekan telah mencapai nilai maksimum. Hasil perhitungan kehilangan pratekan disajikan dalam bentuk histogram secara berurutan pada Gambar 4, 5, 6 dan 7 . Kehilangan pratekan dinyatakan dalam persen terhadap besarnya tegangan awal baja pratekan $\left(\mathrm{f}_{\mathrm{si}}\right)$.

Gambar 4 menunjukkan bahwa kehilangan pratekan akibat susut mempunyai rata-rata sebesar $3.86 \%$ dan koefisien penyebaran (COV) sebesar 57\%, sementara Gambar 5 menunjukkan kehilangan pratekan akibat rangkak mempunyai rata-rata sebesar $10.05 \%$ dan koefisien penyebaran sebesar $35 \%$. Hasil ini sesuai perkiraan bahwa kehilangan pratekan akibat susut akan mempunyai koefisien penyebaran lebih besar dibandingkan akibat rangkak karena model error untuk susut mempunyai koefisien penyebaran yang lebih besar dibandingkan model error untuk rangkak.

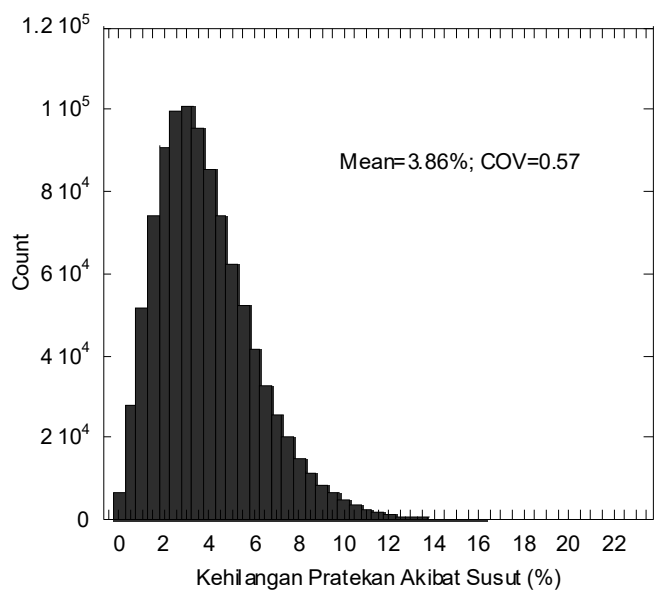

Gambar 4: Kehilangan Pratekan Akibat Susut Beton.

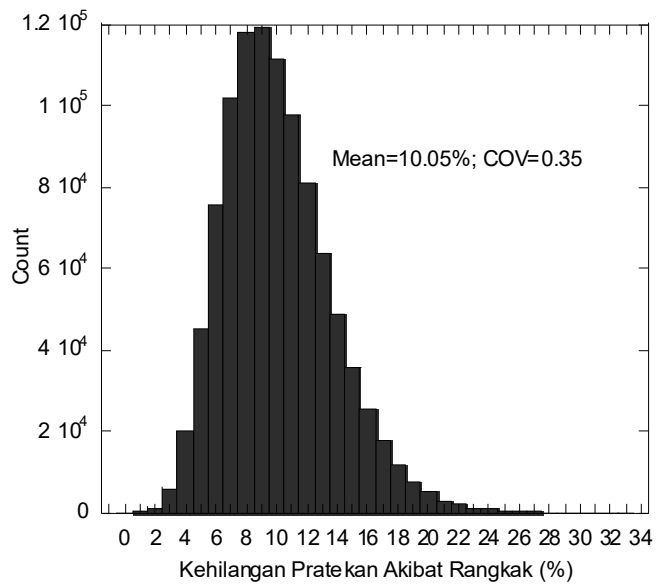

Gambar 5: Kehilangan Pratekan Akibat Rangkak Beton. 
Gambar 6 menunjukkan kehilangan pratekan akibat relaksasi pada baja, dimana diperoleh nilai rata-rata sebesar $4.31 \%$ dengan koefisien penyebaran sebesar $18 \%$.

Gambar 7 selanjutnya menunjukkan kehilangan pratekan akibat kombinasi susut dan rangkak pada beton serta relaksasi pada baja, dimana diperoleh nilai rata-rata sebesar $18.22 \%$ dengan koefisien penyebaran sebesar $25 \%$.

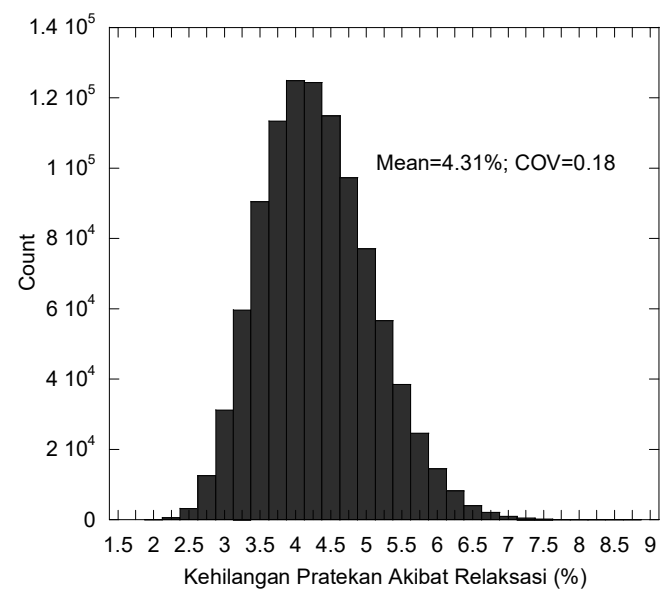

Gambar 6: Kehilangan Pratekan Akibat Relaksasi Baja.

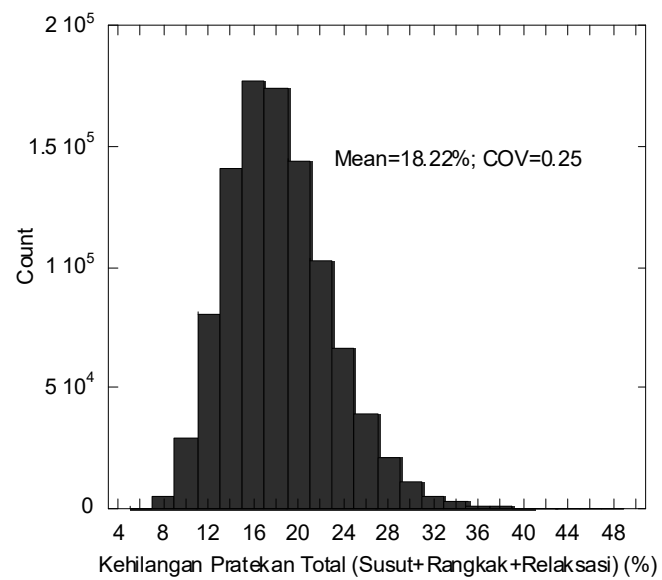

Gambar 7: Kehilangan Pratekan Akibat Susut dan Rangkak Beton serta Relaksasi Baja.

Gambar 8, 9, 10 dan 11 secara berurutan menyajikan distribusi kehilangan pratekan akibat susut dan rangkak beton serta relaksasi pada baja dan kombinasi dari ketiga faktor tersebut.

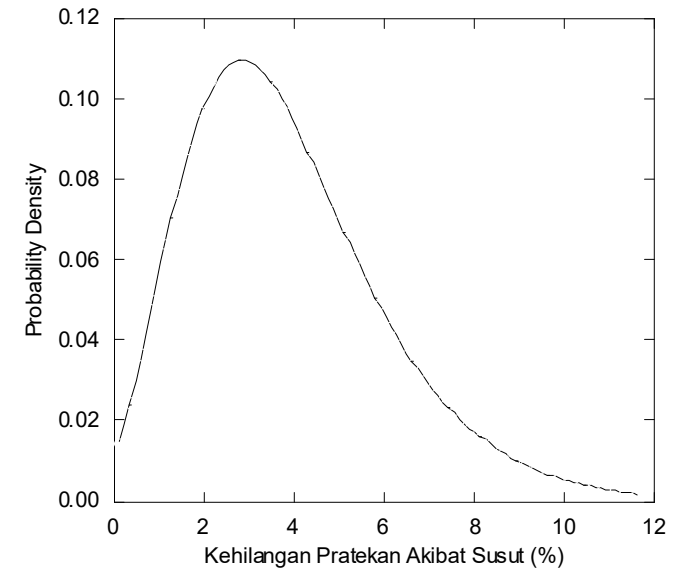

Gambar 8: Distribusi Kehilangan Pratekan Akibat Susut.

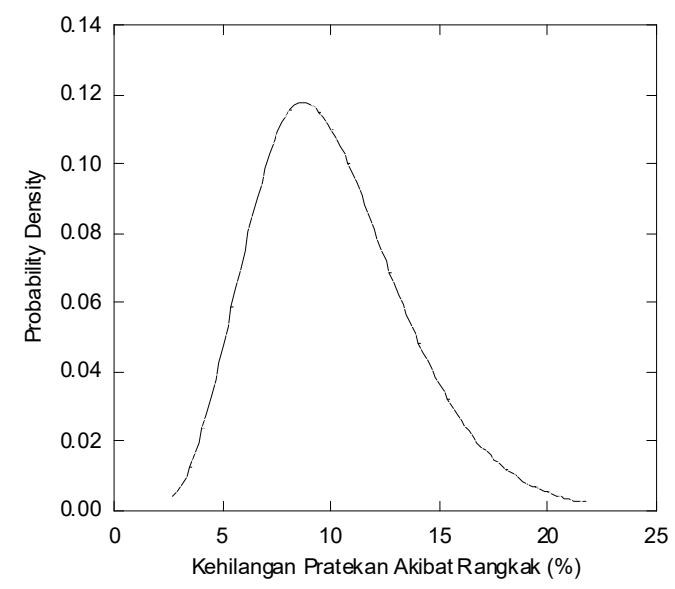

Gambar 9: Distribusi Kehilangan Pratekan Akibat Rangkak.

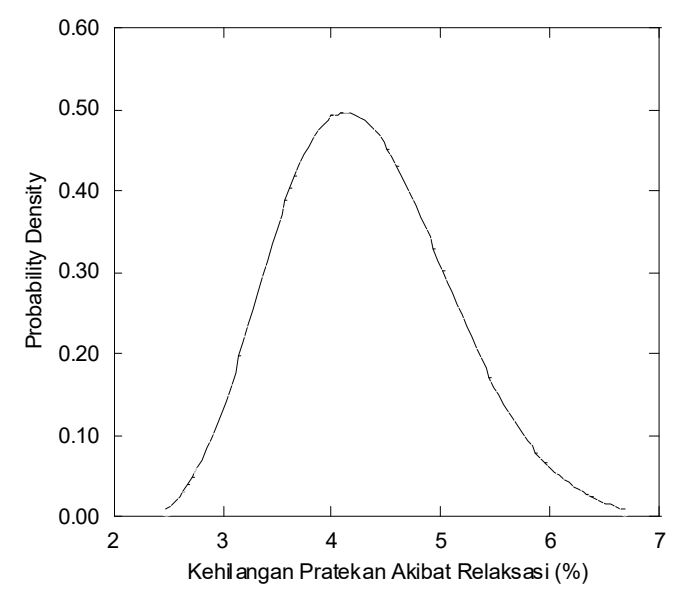

Gambar 10: Distribusi Kehilangan Pratekan Akibat Relaksasi. 


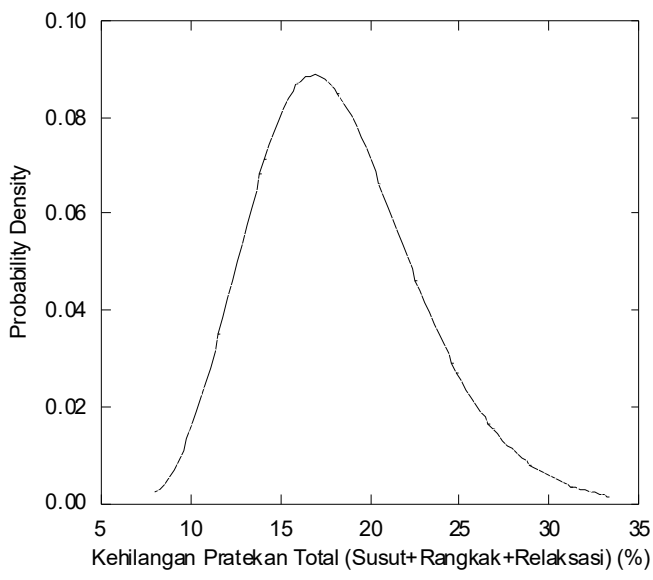

Gambar 11: Distribusi Kehilangan Pratekan Akibat Susut dan Rangkak Beton serta Relaksasi Baja.

Gambar 8, 9, 10 dan 11 telah secara jelas menunjukkan bahwa nilai kehilangan pratekan mempunyai variasi yang cukup besar. Dengan demikian perlu diperhatikan bahwa nilai kehilangan pratekan yang diperoleh dengan cara deterministik (mengabaikan variasi sifat-sifat beton) ada kemungkinan tidak akurat. Nilai yang diperoleh secara deterministik tersebut, pada umumnya merupakan nilai yang mendekati rata-rata dari besarnya kehilangan pratekan. Nilai yang didapat secara deterministik (rata-rata) tersebut mempunyai kemungkinan sebesar $\pm 50 \%$ akan terlampaui. Hampir semua code telah memberi peringatan kemungkinan ketidaktepatan nilai kehilangan pratekan yang diperoleh berdasarkan perumusan yang diberikan dalam code. Untuk itu diperlukan kehati-hatian dalam menentukan besarnya kehilangan pratekan karena akan berpengaruh kepada tingkat pelayanan balok pratekan, misalnya besarnya lendutan atau retak yang diluar perkiraan.

\section{KESIMPULAN}

Hasil studi menunjukkan bahwa perhitungan kehilangan pratekan akibat susut dan rangka beton serta relaksasi pada baja dengan memperhitungkan variabilitas sifat-sifat beton dan baja pratekan mempunyai pengaruh yang cukup besar. Dengan memasukkan pengaruh variasi dan ketidaktentuan sifat-sifat beton dan baja, didapatkan bahwa kehilangan pratekan akibat susut mempunyai rata-rata sebesar $3.86 \%$ dengan koefisien penyebaran sebesar $57 \%$, kehilangan pratekan akibat rangkak mempunyai rata-rata sebesar $10.05 \%$ dengan koefisien penyebaran yang lebih kecil, yaitu sebesar 35\%. Sedangkan kehilangan pratekan akibat relaksasi baja mempunyai rata-rata sebesar $4.31 \%$ dengan koefisien penyebaran sebesar 18\%. Akibat kombinasi susut dan rangkak beton serta relaksasi baja, kehilangan pratekan mempunyai ratarata sebesar $18.22 \%$ dengan koefisien penyebaran sebesar $25 \%$.

\section{DAFTAR ACUAN}

ACl 318 (2002), Building Code Requirement for Sructural Concrete ( $\mathrm{ACl}$ 318-02) and Commentary (ACl 318R-02), American Concrete Institute, Farmington Hills, Michigan.

ACl Commitee 209 (1992), Prediction of Creep, Shrinkage and Temperature Effects in Concrete Structures $(\mathrm{ACl}$ 209), ACl Manual of Concrete Practice, American Concrete Institute, Farmington Hills, Michigan.

AS 3600 (2001), Concrete Structures, Standards Association of Australia, Homebush, New South Wales, Australia.

Attard, M. M. and Stewart, M. G. (1998), A Two Parameter Stress Block for Model for High Strength Concrete, $\mathrm{ACl}$ Structural Journal, ACl, Vol. 95, No. 3, pp. 305-317.

Bazant, Z. P. and Baweja, S. (1995), Creep and Shrinkage Prediction Model for Analysis and Design of Concrete Structures-model B3, Materials \& Structures, Vol. 28, pp. 357-365.

Comite Euro-International du Beton (1990), CEB-FIP International recommendations for the design and construction of concrete structures, CEB-FIP Code 90, Paris-London.

Gilbert, R. I. (1988), Time Effects in Concrete Structures, Elsevier, New York, USA. 
Gilbert, R. I. and Mickleborough, N. C. (1990), Design of Prestressed Concrete, Unwin Hyman Ltd, London.

Khor, E. H. (1999), Early-age Effects on Serviceability Reliability of Reinforced Concrete Flexural Members, PhD Thesis, Department of Civil Engineering, Clemson University, SS, USA.

Koutsoukis, M. (1996), On the Probabilistic Time-dependent Axial Shortening of Tall Concrete Building, PhD Thesis, Department of Civil and Mechanical Engineering, University Tasmania, Australia.

Mirza, S. A., Hatzinikolas, M. and MacGregor, J. G. (1979), Statistical Description of Strength of Concrete, Journal of the Structural Division, ASCE, Vol. 105, No. ST6, pp. 1021-1037.
Mirza, S. A., Kikuchi, D. K. and MacGregor, J. G. (1980), Flexural Strength Reduction Factor for Bonded Prestressed Concrete Beams, ACl Journal, Vol. 77, No. 4, pp. 237-246.

Mirza, S. A. and MacGregor, J. G. (1979b), Variations in Dimensions of Reinforced Concrete Members, Journal of the Structural Division, ASCE, Vol. 105, No. ST4, pp. 751-766.

Stewart, M. G. (1996), Serviceability Reliability Analysis of Reinforced Concrete Structures, Journal of Structural Engineering, ASCE, Vol. 122, No. 7, pp. 794-803. 